\title{
Detecting invasive woody increment in agricultural areas with Earth Observation technology
}

\author{
Györk Fülöp ${ }^{1}$, Gábor Bakó ${ }^{2}$ Boglárka Szabó ${ }^{3}$
}

\section{N F O \\ Received 18 Nov 2014 \\ Accepted 29 Dec 2014 \\ Available on-line 14 Jan 2015 \\ Responsible Editor: M. Herdon}

Keywords:

remote sensing, invasive woody increment, biomass monitoring, Earth Observation, T-BEA

\begin{abstract}
A B S TRACT
In the continental climate regions of the $\mathrm{EU}$, one of the largest environmental and conversational problems is caused by the spread of invasive plant species, especially in agriculturally abandoned regions. Several species of the rapidly spreading and to the native vegetation supplanter plant can be a cause of ecologic and health risk. Some species change the physical structure and chemical composition of the soil, affect the microclimate, thereby contributing to climate change processes. Summing up, invasive species affect agricultural landscapes significantly. The common feature of the belonging species is that they spread rapidly and develop a significant amount of biomass in a short time. In the course of our research we worked out a remote sensing and GIS method, which localize efficiently the infected areas, and we utilized this method in the Northern Transdanubia, to extract the information of woody increment in agricultural regions.
\end{abstract}

\section{Introduction}

Curbing the spread of invasive plant species has a significant economic interest. The elimination of the invasive plant species - which endanger the biodiversity, the agricultural productivity and the health of the citizens - is an other important European interest. Since 1992, the EU have spent more than 38 million EUR within the framework of 180 projects to stop the spread of invasive species in natural and agricultural areas [1]. The USA, based on actual estimates, marked out 80 billion EUR resources (annually) for the combat against the biological intruders [2].

Nowadays, the decreasing stock of energy supplies endeavour the application of renewable and alternative energy sources. [3] Consequently, the interests of the energy sector can be set aside to the environmental protection, so an efficient environmental resolution can be drawn up, supporting productivity with environmental planning [4]. The importance of biomass resources has been declared formerly [5], and this importance is increasing from year to year [6]. Bioenergy stands for traditional biomass energy and for sustainable energy source [7]. The biomass volume - which is necessary for the operation of the bio-energy power-plants is getting harder to be accessible, since the cultivated energy plantations destroy the topsoil [8]. For the previously built power plants, it is increasingly useful to operate with biomassstock of invasive vegetation, which is causing environmental damage. However, this demand

\footnotetext{
${ }^{1}$ Györk Fülöp

Development \& project manager - GeoData Services Ltd.

Assistant of professor - Department of Biometry and Agricultural Informatics, Faculty of Horticultural Sciences, Corvinus University of Budapest

${ }^{2}$ Gábor Bakó

Developing geoinformaticians - GeoData Servivces Ltd.

PhD candidate - Institute of Botany and Ecophysiology, Faculty of Agricultural and Environmental Sciences, Szent István University

${ }^{3}$ Boglárka Szabó

Developing geoinformaticians - GeoData Servivces Ltd.

PhD student - Institute of Environmental and Landscape Management, Faculty of Agricultural and Environmental Sciences, Szent István University
} 
raise the yet unsolved question of biomass detection as input data for sustainable management [9]

Primarily, the woody, quickly renewable species came into the focus of interest [10-1112], E.g. Tree of Heaven (Ailanthus altissima), Russian Olive (Elaeagnus angustifolia), Black Pine (Pinus nigra), Common Hackberry (Celtis occidentalis). Although, the non-indigenous herbs can cause serious environmental problems in the European landscapes [13]. In our study we worked out the methodology to detect the woody increment. Our aim - in compliance with the appropriate renewable energy directive - was to promote the excavation of such renewable energy directive control [14], which has no conservation or forestry value, but they threat the native vegetation and the ecosystem.

In order to achieve these objectives, it was necessary to examine the cost-effective Earth Observation (satellite remote sensing) and image information mining techniques, which can monitor the renewable production of woody incremental biomass stocks. The ongoing EUREKA labelled [15] T-BEA project [16] (Tool for Biomass Energy Accessibility with Earth Observation) is aiming to detect with Earth Observation tools efficiently the biomass stocks, which are sustainable to be utilized for bio-energetic use, and which mean significant danger for the natural and agricultural environment.

In the first phase of the investigation, we looked for the answer, how we can approach to the technical challenge by using exclusively freely available Earth Observation datasets. First, we tested the sufficiency of the quoted vegetation indices and the correction calculations with the freely available Landsat 4, Landsat 5 and Landsat 8 satellite images. Then with the set up methodology we extracted spatial information on woody increment sites in the Northern Transdanubia, to support future operative biomass quantity measurements by categorizing this region in a robust way in function of accessible biomass (agricultural sites with woody increment). We present the first test and validation results, which may draw up the frame for the future developments.

\section{Data sources}

The procurement of images came true across the website of USGS Earth Explorer. The Landsat 4 was operating between July 16, 1982 and December 14, 1993, while the Landsat 5 mission between March 1, 1984 and January 2013. Thematic Mapper functioning of the onboard (TM) sensor acquired the images in seven spectral bands (Table 1). The uncompressed images are georeferenced, and have mapping projection, they require for each channel an average $60 \mathrm{MB}$ storage space, and they are more than $8000 \times 7000$ pixels in size.

Table 1. Bands of the Thematic Mapper (platform: Landsat 4-5)

\begin{tabular}{|l|l|l|l|}
\hline Band & \multicolumn{1}{|c|}{ Spectral range } & Spatial resolution & \multicolumn{1}{|c|}{ Description } \\
\hline 1 & $0.45-0.52 \mu \mathrm{m}$ & $30 \mathrm{~m}$ & Blue \\
\hline 2 & $0.52-0.60 \mu \mathrm{m}$ & $30 \mathrm{~m}$ & Green \\
\hline 3 & $0.63-0.69 \mu \mathrm{m}$ & $30 \mathrm{~m}$ & Red \\
\hline 4 & $0.76-0.90 \mu \mathrm{m}$ & $30 \mathrm{~m}$ & Near-Infrared \\
\hline 5 & $1.55-1.75 \mu \mathrm{m}$ & $30 \mathrm{~m}$ & Near-Infrared \\
\hline 6 & $10.40-12.50 \mu \mathrm{m}$ & $120 \mathrm{~m}$ & Thermal \\
\hline 7 & $2.08-2.35 \mu \mathrm{m}$ & $30 \mathrm{~m}$ & Mid-Infrared \\
\hline
\end{tabular}

A Landsat 8 satellite entered service on May 30, 2013. The imaging bands of Operational Land Imager (OLI) sensor differ from the bands of TM sensor, therefore in case of the two 
different type of imagery respectively different calculations shall be done. The OLI sensor specifications are presented in Table 2.

Table 2. Bands of the Operational Land Imager (OLI) (platform: Landsat 8)

\begin{tabular}{|l|l|l|l|}
\hline Band & \multicolumn{1}{|c|}{ Spectral range } & Spatial resolution & \multicolumn{1}{c|}{ Description } \\
\hline 1 & $0.433-0.453 \mu \mathrm{m}$ & $30 \mathrm{~m}$ & Coastal / Aerosol \\
\hline 2 & $0.450-0.515 \mu \mathrm{m}$ & $30 \mathrm{~m}$ & Blue \\
\hline 3 & $0.525-0.600 \mu \mathrm{m}$ & $30 \mathrm{~m}$ & Green \\
\hline 4 & $0.630-0.680 \mu \mathrm{m}$ & $30 \mathrm{~m}$ & Red \\
\hline 5 & $0.845-0.885 \mu \mathrm{m}$ & $30 \mathrm{~m}$ & Near Infrared \\
\hline 6 & $1.560-1.660 \mu \mathrm{m}$ & $30 \mathrm{~m}$ & Short Wavelength Infrared \\
\hline 7 & $2.100-2.300 \mu \mathrm{m}$ & $30 \mathrm{~m}$ & Short Wavelength Infrared \\
\hline 8 & $0.500-0.680 \mu \mathrm{m}$ & $15 \mathrm{~m}$ & Panchromatic \\
\hline 9 & $1.360-1.390 \mu \mathrm{m}$ & $30 \mathrm{~m}$ & Cirrus \\
\hline
\end{tabular}

The uncompressed images are georeferenced, and have mapping projection, they require an average of $120 \mathrm{MB}$ storage space at each channel, and they consist of more than $8000 \mathrm{x}$ 8000 pixels. Since the satellite images are available in georeferenced form, after the uncompressing, sorting and methodizing, the adjustment process of the evaluation could be started immediately.

\section{Methods}

The set up methodology aimed to frame the servicing GIS infrastructure, which shall be used operatively in the near future to detect accessible, unused and sometimes even harmful biomass stocks with Earth Observation technology. The introduced solutions stand for only the first phase of the development chain, however, with the utilization of these results the information production could be optimized on an objective basis.

\subsection{The applied vegetation indexes and the suggested software}

The NDVI (Normalized Difference Vegetation Index) is a dimensionless value, which express the vegetative activity of a given area. The value of NDVI is supplied by the quotient of difference and the amount between the vegetation reflectance intensities of near infrared (NIR, usually 845 to $885 \mathrm{~nm}$ ) and visible red (RED, usually 630-680 nm) range [17]. The described formula:

$$
\mathrm{NDVI}=\frac{(\mathrm{NIR}-\mathrm{RED})}{(\mathrm{NIR}+\mathrm{RED})}
$$

where:

NIR - Reflectance value of the near infrared band (Landsat 4,5: band 4; Landsat 8: band 5) RED - Reflectance value of the red band (Landsat 4,5: band 3; Landsat 8: band 4)

If the measurement performing sensor is on airplane, or on space-based device, then the disruptive effects of the atmosphere must be taken into account during the measurement of solar radiation at given wavelength. The radiation passing through the atmosphere is subjected to the scattering and absorption, which can be induced by both molecular gas and aerosol particles. To reduce the radiation modifying effects of atmosphere - in order to reduce the dependence of the measured reflectance direction - a bidirectional reflectance distribution function model (BRDF) should be adapted [18]. This process is called atmospheric correction. 
During the atmospheric correction four variables are necessary to be applied:

- $\quad$ Aerosol optical depth at $550 \mathrm{~nm}$

- Quantity of total splillingable water vapour (vertically integrated water vapour)

- Quantity of vertically integrated ozone

- $\quad$ Surface pressure

The latter can be determined from MODIS data, which can be an alternative way of field data collection and purchase of archive meteorological data. MODIS is an ideal choice, since the data can be obtained from more than 150 crossings a year.

The determination of the vegetation index - in case of images, which have been normalized and undergone the atmospheric corrections - is supported by a number of different software. Calculation of NDVI from Landsat images is realized in the following way:

We can produce NDVI maps with the help of ArcMap, after the loading of appropriate bands from Landsat with the image analysis module (image Analysis): Select the Processing Toolbox NDVI 'maple leaf'. A new layer will represent the calculation.

Using the ENVI software package we can prepare our maps NDVI map also. In the toolbar (Toolbox), select the Spectral / Vegetation / NDVI option. So in the appearing NDVI window we can select the images will be analysed and we can narrow the calculation with a selection tool for the area of the image. We can select the type of image, if the sensor is on the list (TM, MSS, AVHRR, etc.), or you can give the appropriate red and near-infrared bands of opened image (in case of known sensor the software selects the appropriate bands). We need to decide that do we export the result into the computer's memory, or we specify the file format.

In the ERDAS 2011 software package can be found NDVI module, we can achieve this to click the Raster / Multispectral / Unsupervised tab, for the type of NDVI classification. Setting of this is similar to the ENVI NDVI panel. Of course, in this case, we gave values between -1 and 1 for each pixel and the positive integer means the healthy green vegetation.

NDVI calculation is also supported by the SPRING GIS. First, here we open the image also, and then we click to the Image tab and select the option of Arithmetic Operations. At the Operations button we select the "C = Gain * ( $(\mathrm{AB}) /(\mathrm{A}+\mathrm{B}))+$ Offset," option, then we give the A channel as the near infrared, while B channel is the red channel. By clicking the button of ColorPallet we can give hues for the outcome. You should choose colours from the often used in the international literature. For example, the White - Yellow - Green tone NDVI colour scale, which provides a good basis for comparison the graphic material of different publications.

The free MultiSpec software is able to perform the NDVI calculation. The images must be open, and then after selecting the Reformat option from the Processor menu, click the Change Image File Format. In the appearing dialog we can select the output format (you should use *.geoTIF), then we can load the Transform data box, which calls for a new dialog box. Here select the New Channel from General Algebraic Transformation opportunity. After we have accepted it, a new window appears, into which we can write the wanted formula, in this case:

$$
\mathrm{NDVI}=0+\frac{1.0 \mathrm{C} 3-1.0 \mathrm{C} 2}{1.0 \mathrm{C} 3+1.0 \mathrm{C} 2} * 1
$$

where: $\mathrm{C} 1$ and $\mathrm{C} 2$ mark the R and NIR bands.

To perform the calculations we can use the also free GRASS GIS with writing the "r.mapcalc" command. In the GRASS GIS Raster Map Calculator window, firstly we give the 
name of the layer, what we want to create and then we compile the formula. To do this, add the appropriate bands with the Insert existing raster map button. With click to the Run button we can prepare the new NDVI layer.

With the QGIS open source GIS software we also can calculate NDVI after installing the Measuring Vegetation or the Raster Calculator plugin. With at the GRASS software reviewed method gives the formula. The load time of the NDVI layer depends on the size of the used image. On the gray-scale layer, the dark parts of the areas are the less vegetation covered areas. We prepared own algorithm for vegetation index calculation and for the subsequent operations for partially automate the process.

\subsection{The processing of NDVI maps}

In order to retrieve a map from the vegetation coverage, we must give an identification threshold, for the classification of the vegetation and non-vegetation pixels by the software. Thus, we can determine the vegetation covered areas with a relatively simple classifications process. Ultimately, we get two categories: vegetation and bare surfaces.

The extraction of vegetation indexes can be achieved with the performed mathematical operations on the raster file bands, result a new raster band, a coverage map. Since the selection of the woody growth is our aim, after it we need to compare the coverage maps of different months, for that we can filter out the harvested plots covered with herbs and spring herbaceous weeds. In this way we get a woody cover overlay for every year, which from create vector, a digital map obtained, which can be compared with the forestry and conservational digital databases. So we can quickly and automatically mark the areas covered with woody weed increment with the taking into consideration the vegetation cover of previous years.

First, we give a threshold, where the higher NDVI values belong to the areas, which are interesting for us and which are covered by vegetation in the whole vegetation period. If at the NDVI calculation we did not apply atmospheric correction and normalization calculations, than this value will be empirically determined (Tab. 3). The difference between satellite datasets are arising from the spectral difference of the acquisitioned sensor bands, while between the seasons the atmosphere may cause the main difference.

Table 3. The applied NDVI thresholds in case of our working area

\begin{tabular}{|c|c|c|}
\hline Satellite & Images of the summer months & Images of early spring and autumn \\
\hline Landsat 8 & NDVI 0.44 & NDVI 0.35 \\
\hline Landsat4 and 5 & NDVI 0.53 & NDVI 0.44 \\
\hline
\end{tabular}

Then, we give the cover of biomass areas in a given year from the cutaway of the given acquisition dates of the characteristic plant biomass cover maps (Fig. 1). Where a rapid growth of biomass can be observed in the consecutive years, there appear likely invasive, but at least R-strategist species. We can detect the largest plant infections efficiently with this monitoring system. 


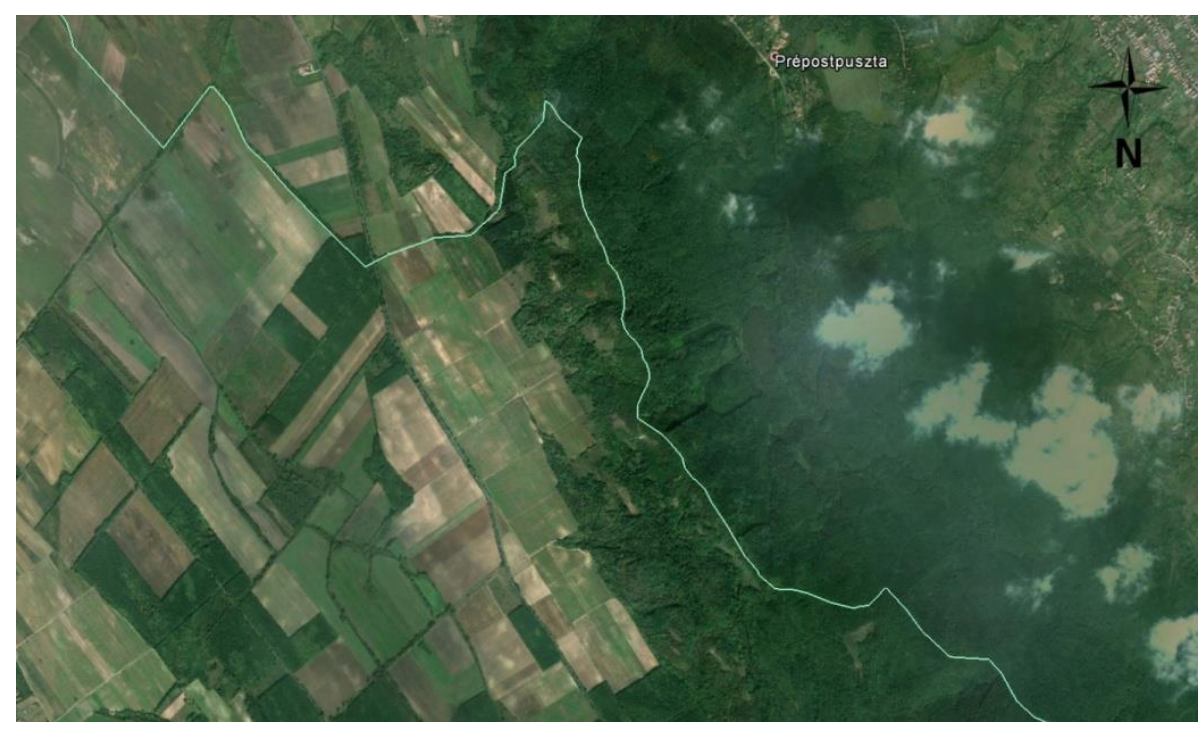

Figure 1a. Test area (illustration background source: Google Earth)

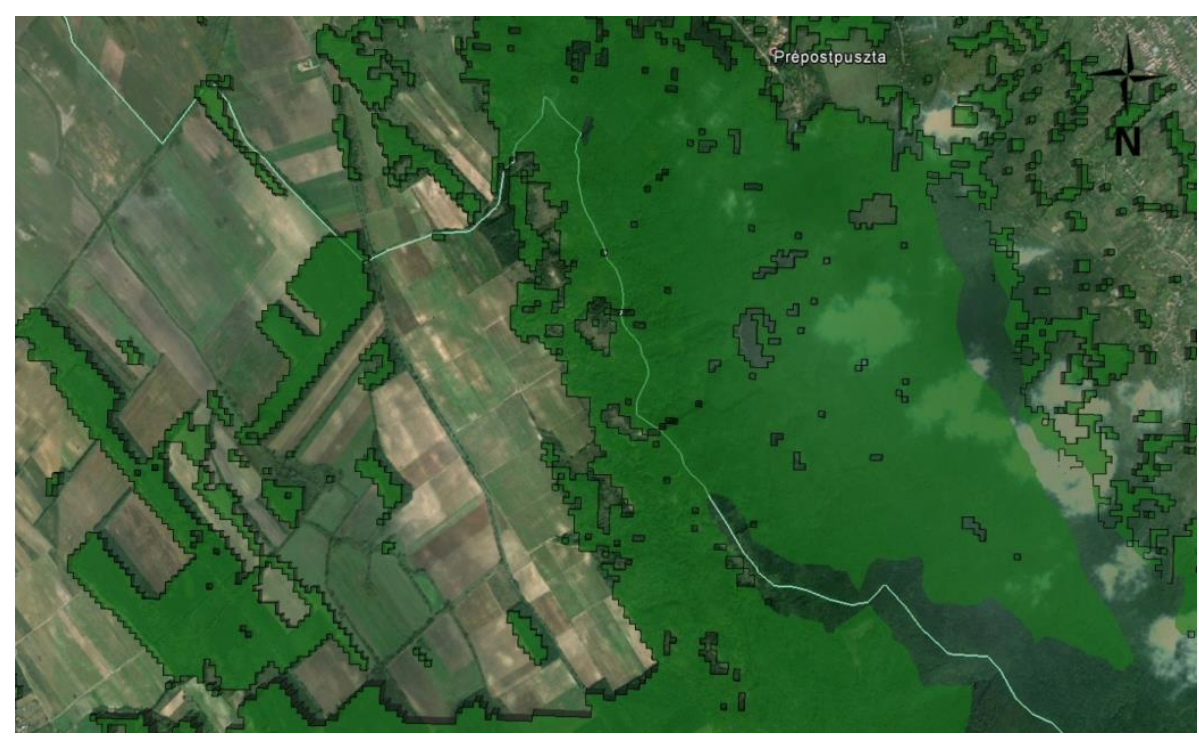

Figure 1b. Woody biomass cover map of the year 2011 controlled with GeoEye space images (illustration background source: Google Earth)

\subsection{In situ validation}

During the test process we found that the created monitoring system digest the fastgrowing photosynthetic biological production with 60 meters resolution. The areas infected by Ailanthus altissima can be detected very well (Fig. 2). 


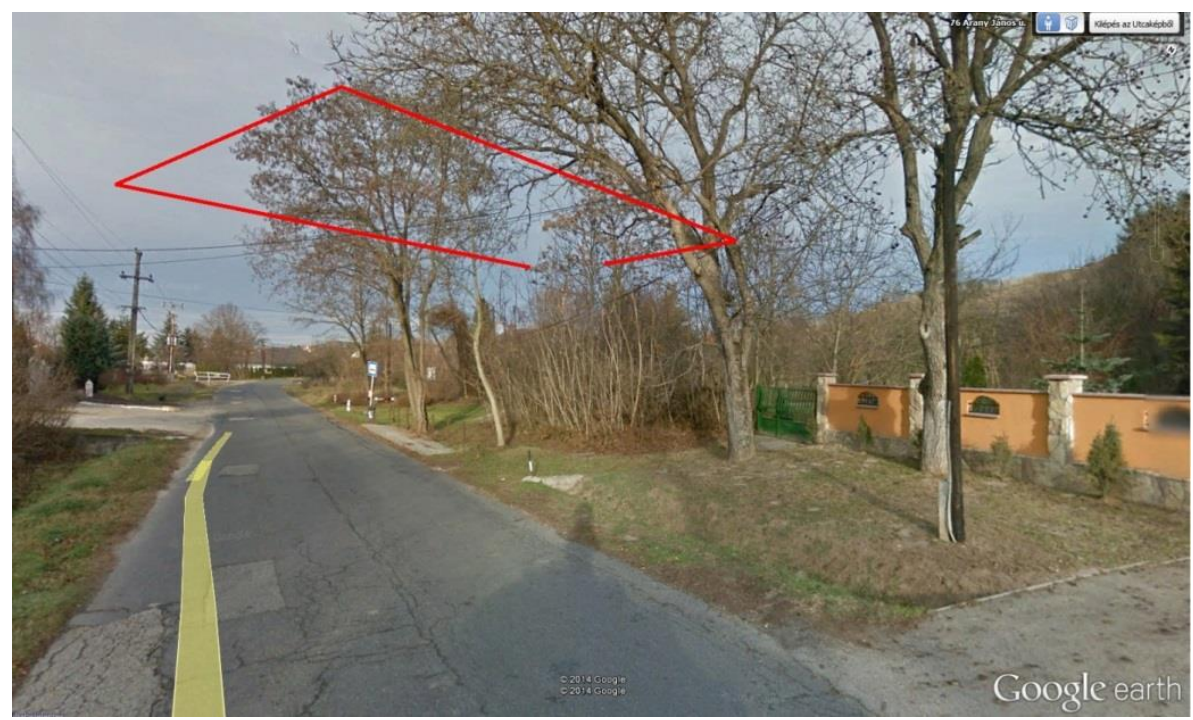

Figure 2. The area is infected by Ailanthus altissima presented in the Google street view service. The red line is the boundary of polygon from our monitoring system

The smallest detected increment areas are $3600 \mathrm{~m} 2$ (Fig. 3). Due to the limitation of Landsat images resolution, the mapping output may not be accurate at the desired level, however it is adequate for detection, thus the necessary interventions can be performed. The method application is useful for local and national environmental protection, since it calls attention to the large increment areas, which - literally - are the bad seeds in the landscape.
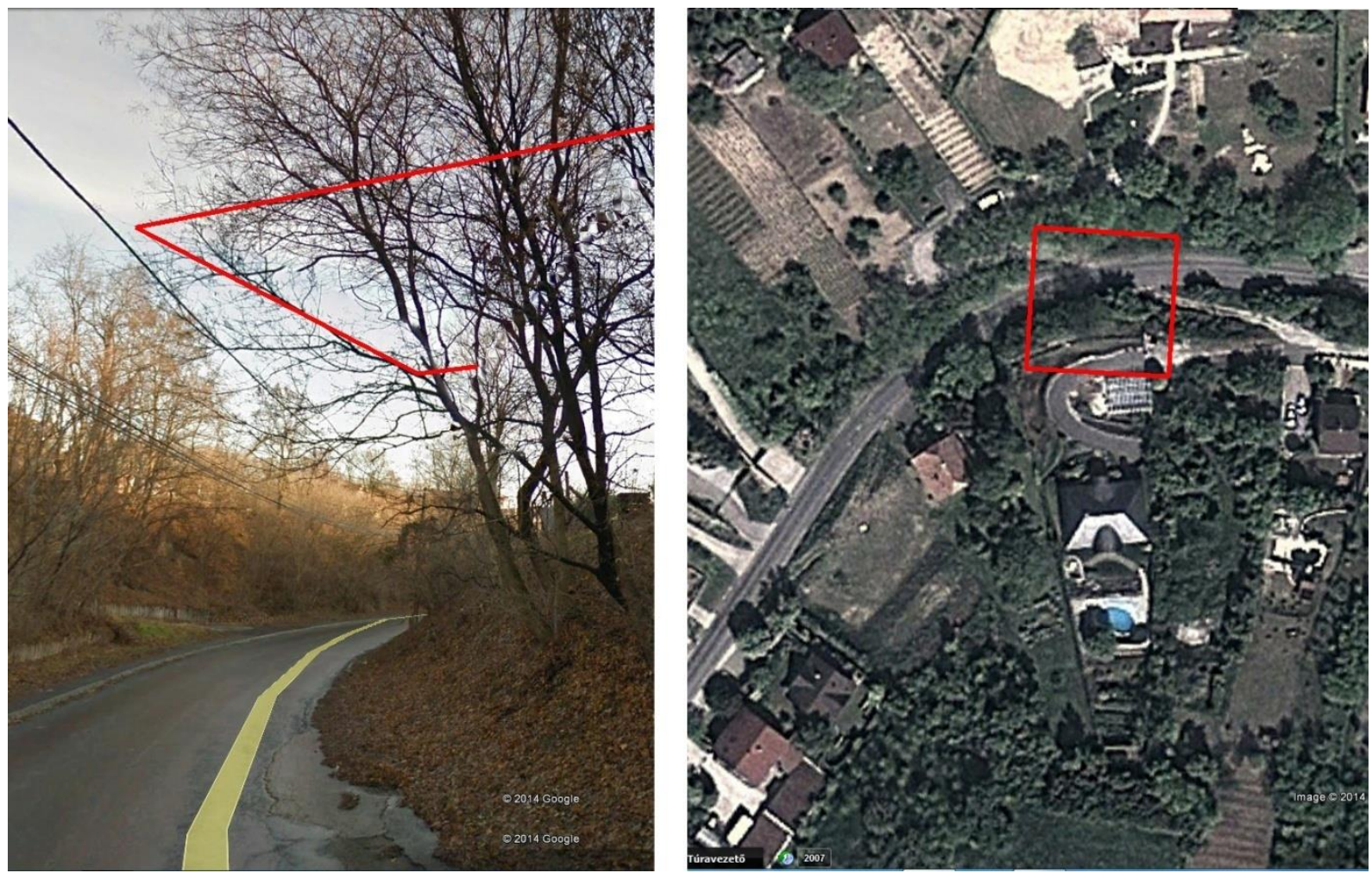

Figure 3. Increment areas in the Google Earth service. The red line is the boundary of polygon from our monitoring system. 


\section{Results}

We applied the described methodology in the region of Northern Transdanubia (north from Lake Balaton) with the utilization of Landsat 8 imagery (Figure 5). Our aim was to define the regions, in which it is the most cost-efficient to start more detailed remote sensing based measurements (Copernicus Sentinel-1 data PolInSAR technology and sampling with MS VHR imagery) in order to estimate the quantity of invasive biomass (ton/ha).

In the region of interest we have detected 3439 (administratively) agricultural sites with invasive woody increment, which are occupying 8133 ha. We categorized these sites into three groups according to land use categories. The distribution of the sites can be seen in Figure $4 a-b$.

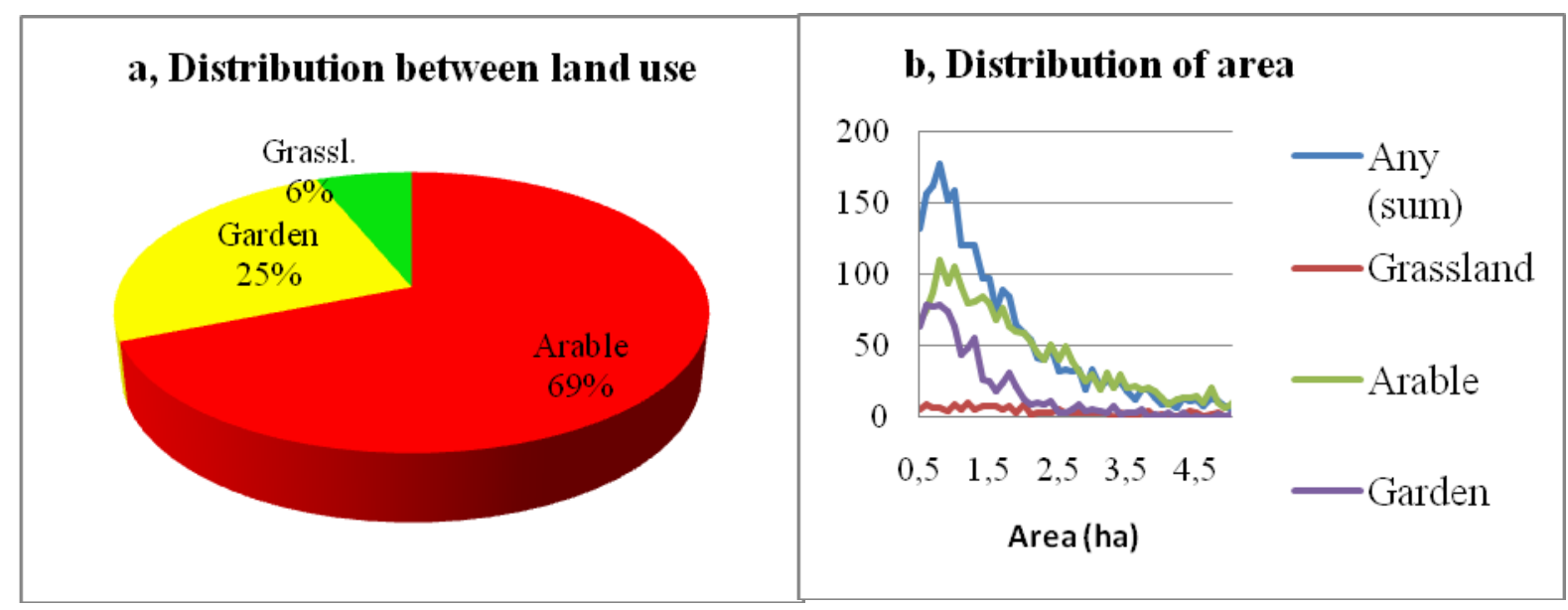

Figure 4 a-b. Distribution of detected invasive woody increment sites

The average size of the detected sites is 2,37 ha (deviation 2.55, median: 1.60); understandably, the biggest sites were detected in areas, which are used as grasslands (average area: 2.96 ha, deviation: 2.58, media: 2.05 ha); then the following largest ones are under arable land use (average area: 2.69, deviation: 2.84, median: $1.80 \mathrm{ha}$ ); and finally the sites with agricultural-gardening land use are the smallest ones (average area: 1.36 ha, deviation: 0.95, median: 1.10).

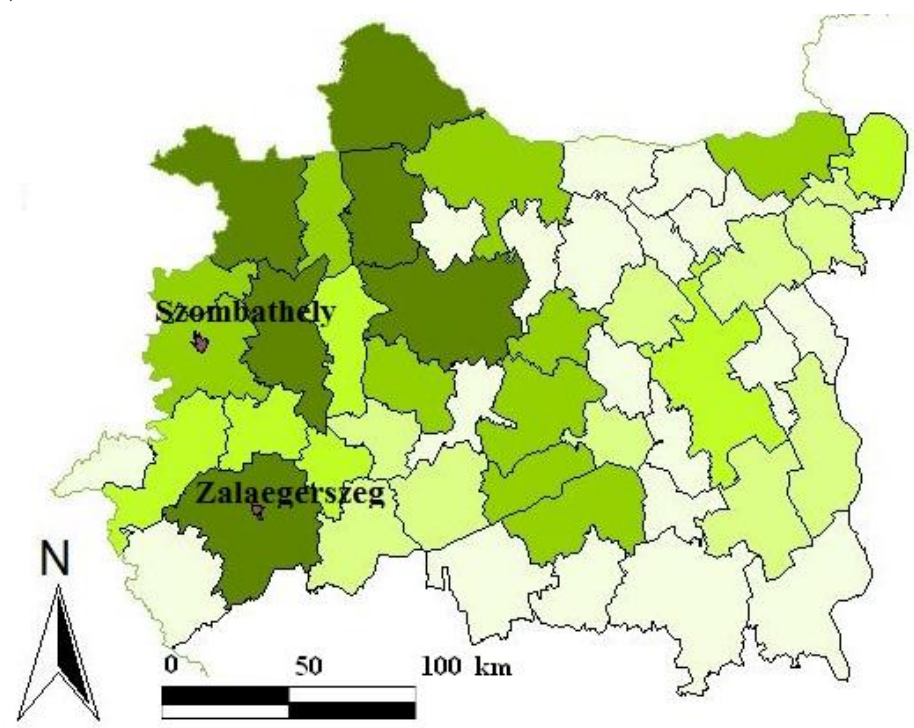

Figure 5. Spatial distribution of the detected invasive woody increment sites between the townships 
In order to prepare spatial overview of the distribution of the detected sites, we have created categorical maps with the use of LAU 1 scale administrative regions ("járások" townships), presenting the summarized area (Figure 5), the number and the distribution of the detected sites.

If we weigh the townships with the average area and number of detected invasive woody increment sites and with the reciprocal of the township area (density) we find a quite interesting ranking order. The first two townships (Szombathelyi járás and Zalaegerszegi járás and) are organized around cities, which are also seats of counties (Vas and Zala county) (NUTS 4) - and not as suspected, regions, where villages dominate. The possible explanation of this phenomenon could be dual. The experiment was focusing on agricultural areas, and in regions, where the effects of urbanisation has a significant impact, more agricultural areas are abandoned. The other explanation can be that invasive species often turn up due to activities, which are related sub-urban land use (logistic and industry areas, heavy transportation) and they are spreading from there in the direction of agricultural areas.

In situ validation took place in the townships of Györ and Komárom. The validation process was carried out by a stakeholder partner from biomass industry. The validation results are described in Tab 4.

Table 4. Validation results of EO detection of biomass sites

\begin{tabular}{|l|c|}
\hline Number of detected sites & 130 \\
\hline Cumulated area of sites & $261 \mathrm{ha}$ \\
\hline Number of in situ validated sites & 73 \\
\hline Cumulated area of validated & $169,4 \mathrm{ha}$ \\
\hline Number of well-detected & $66(90 \%)$ \\
\hline Number of false detection & $6(10 \%)$ \\
\hline Number of efficient to exploit & $41(56 \%)$ \\
\hline Area of efficient to exploit & $91 \mathrm{ha}$ \\
\hline Estimated attro ton (valuable material) & $4575 \mathrm{ton}$ \\
\hline
\end{tabular}

\section{Conclusions}

Although the 30-m spatial-resolution HS and MS images is not allowing the racial and association-level vegetation mapping in diverse environment, they are suited for building a rapid and cost-effective biomass monitoring system. With the Landsat images, which are available for free we can achieved the annual monitoring of woody plant biomass with $60 \mathrm{~m}$ detail. So the created IT system indicates that somewhere R strategist species appear suddenly and in great crowd. Due to the control of such areas, the plant infections can be localized, and at the same time the most infected areas can provide the greatest output of invasive species and related biomass stock. With the utilization of the set up methodology the optimization of the processing chain can be started in an iterative manner, providing a strong basis for developing an operatively adequate technology in order to serve the energy-efficiency and the nature protection aims in a synergetic way.

\section{Acknowledgements}

The preparation of this publication was helped by the EUREKA labelled T-BEA project (EUREKA Secretariat E!7651) coordinated by the National Innovation Office (EUREKA_HU_121-2012-0042 project), lead by GeoData Services Ltd. - Hungary. 


\section{References}

[1] EUROPEAN COMMISSION, Commission presents policy options for EU strategy on invasive species, Brussels: 5 December 2008. 20 pp. European Commission - IP/08/1890.

[2] ASNER, G.P. \& VITOUSEK P.M. Remote analysis of biological invasion and biogeochemical change.PNAS. 2005, vol. 102 no. 12 March 22, pp. 4383-4386. ISSN 1234-5678. doi:10.1073/pnas.0500823102

[3] EUROPEAN COMMISSION, Renewables Directive - Brussels: 2009/28/EC, 23 April 2009

[4] JOSHUA G. The Elusive Green Economy. The Atlantic July/August 2009 http://www.theatlantic.com

[5] LÁNG I., HARNOS ZS., CSETE L., KARLOVÁNSZKY, U.P., TŐKÉS, O. (1985) A biomassza komplex hasznosításának lehetőségei. Mezőgazdasági Kiadó, Budapest.

[6] QUASCHING, V. (2003) Die Rolle Regenerativer Energien bei der weltweiten Elektrizitätserzeugung. Energiewirtschaftliche Tagesfragen, 2003. 53/5. pp 290-293

[7] WISEMAN J., EDWARDS T. LUCKINS K., Post carbon pathways Melbourne Sustainable Society Institute, University of Melbourne CPD Discussion Paper Melbourne: April 2013 p. 21

[8] GLIESSMAN S. R. (1990) Agroecology: Researching the ecological basis for sustainable agriculture. Ecological Studies 1990. 78. pp 3-10. doi:10.1007/978-1-4612-3252-0_1

[9] ANDREOPOULOU Z., KOLIOUSKA c., TSEKOUROPOULOS G. (2012). Strategic planning and decision support in small-medium wood enterprises using database technology. Journal of Agricultural Informatics (2012) 3/1 pp. 36-45 doi: 10.17700/jai.2012.3.1.85

[10] JANZSÓ J., (1989) Mezőgazdasági és erdészeti melléktermékek hőhasznosítása. Tanulmány.

[11] GRASSELLI, G. (2005) Aprítéktüzelésủ erőmű tüzelőanyag igényének biztosítása. MTA AMB Kutatási és Fejlesztési Tanácskozás. Gödöllö. SZIE, Gépészmérnöki Kar

[12] SZEMMELVEISZ T. (2006) Fás- és lágyszárú biomasszák tüzelhetőségi feltételeinek vizsgálata. Doktori értekezés. Miskolci Egyetem, Müszaki Anyagtudományi Kar Tüzeléstani és Hőenergia Tanszék.

[13] BAKÓ G., Növényi invázió a Balatonnál. Élet és Tudomány LXVIII. 2013/35 pp. 1104-1106.

[14] EUROPEAN PARLIAMENT \& COUNCIL, Renewables Directive 2009/28/EC, L140, 5 June 2009, pp. $16-62$

[15] http://www.eurekanetwork.org/ (29.04.2014 9:29 CET)

[16] http://www.eurekanetwork.org/project/-/id/7651 (29.04.2014 9:30 CET)

[17] ROUSE J.W., HAAS R.H., SCHELL J. A., DEERING D.W. Monitoring the vernal advancement and retrogradation (green wave effect) of natural vegetation. Prog.Rep. RSC 1978-1, Remote Sensing Centre, Texas A\&M Univ., College Station, 93p.(NTIS No. E73-106393)

[18] KERN A. Production of remotely sensed vegetation index data from MODIS and AVHRR, Dissertation Eötvös Loránd University, Budapest: 2011 